\title{
Submicron scale stereolithography using HD-DVD optical pickup unit
}

Chang, Tien-Jen; Vaut, Lukas; Voss, Martin; Ilchenko, Oleksii; Nielsen, Line Hagner; Boisen, Anja; Hwu, En Te

Publication date:

2021

Document Version

Peer reviewed version

Link back to DTU Orbit

Citation (APA):

Chang, T-J., Vaut, L., Voss, M., Ilchenko, O., Nielsen, L. H., Boisen, A., \& Hwu, E. T. (2021). Submicron scale stereolithography using HD-DVD optical pickup unit. Abstract from 2021 SPIE Photonics West.

\section{General rights}

Copyright and moral rights for the publications made accessible in the public portal are retained by the authors and/or other copyright owners and it is a condition of accessing publications that users recognise and abide by the legal requirements associated with these rights.

- Users may download and print one copy of any publication from the public portal for the purpose of private study or research.

- You may not further distribute the material or use it for any profit-making activity or commercial gain

- You may freely distribute the URL identifying the publication in the public portal

If you believe that this document breaches copyright please contact us providing details, and we will remove access to the work immediately and investigate your claim 


\title{
Submicron scale stereolithography using HD-DVD optical pickup unit
}

\author{
Tien-Jen Chang*, Lukas Vaut, Martin Voss, Oleksii Ilchenko, Line Hagner Nielsen, Anja Boisen \\ and En-Te Hwu \\ The Danish National Research Foundation and Villum Foundation's Center for Intelligent Drug \\ Delivery and Sensing Using Microcontainers and Nanomechanics (IDUN), Department of Health \\ Technology, Technical University of Denmark, 2800 Kgs. Lyngby, Denmark
}

\begin{abstract}
It is challenging for stereolithography systems to print submicron features without two-photon lasers. For the first time, we implement an HD-DVD optical pickup unit (OPU) for building a customized stereolithography 3D printer. The OPU equips a $405 \mathrm{~nm}$ single-photon laser and an objective lens with a numerical aperture of 0.65 . This has a focal laser spot diameter of $430 \mathrm{~nm}\left(1 / \mathrm{e}^{2}\right)$ and can thereby, achieve submicron scale features photopolymerization. Moreover, the OPU embeds astigmatic optical path and voice coil motor which can be used for closed-loop printing alignment and this increases printing stability significantly. The OPU 3D printing system integrates an XYZ linear stage, providing nanoscale positioning resolution and macroscale printing area (c.a. 50 X 50 X $25 \mathrm{~mm}$ ). A commercial photo-resin is utilized for the assessment of the system performance. The OPU printer crosslinks structures ranging from tens of microns down to submicron scale by tuning the printing parameters (laser intensity, printing speed, and photo-resin thickness). After optimization of the system, the OPU printer achieved the highest printing resolution of $210 \mathrm{~nm}$ which is beyond conventional stereolithography systems. Furthermore, several microstructures have been printed for verifying multiple layer printing performance. In conclusion, the mass-produced, low-cost and compact size OPU can not only dramatically simplify the stereolithography 3D printer design, but also achieve submicron printing performance.
\end{abstract}

Keywords: 3D printing, HD-DVD, Optical pickup unit, Stereolithography, Submicron scale 